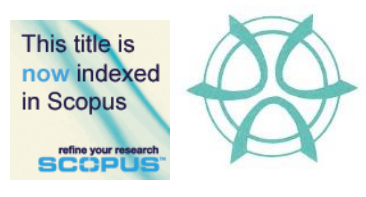

PLANNING MALAYSIA:

Journal of the Malaysian Institute of Planners

VOLUME 16 ISSUE 3 (2018) Page 46 - 56

\title{
ASSESSMENT OF LEARNING WITH NATURE IN PRESCHOOL
}

\author{
Syaida Farizah Saleh ${ }^{1}$, Nurul Syala Abdul Latip ${ }^{2} \&$ Asiah Abdul Rahim ${ }^{3}$ \\ ${ }^{1,3}$ Kulliyyah of Architecture and Enviromental Design \\ INTERNATIONAL ISLAMIC UNIVERSITY MALAYSIA \\ ${ }^{2}$ Faculty of Engineering and Built Environment \\ UNIVERSITI SAINS ISLAM MALAYSIA
}

\begin{abstract}
Learning with nature is a form of psychological therapy for all, including children with disability. Beyond the psychological aspect, access to outdoor green space can also improve social, environmental, developmental, emotional and behavioural, and even medical outcomes. In Malaysia, studies of learning with nature remain scarce due to the Malaysian education system's focus on indoor learning rather than outdoor learning. This research aimed at determining perceptions towards the application of learning with nature among preschool educators. Qualitative methods were used for data collection, consisting of structured interview and field observation. Four preschools were selected as sample. Results show that learning with nature contributes to the positive development of the children. The approaches used to instil nature awareness include conducive landscape, environmental activities, outdoor class activities, outdoor free play, formal education and recreational programme outside a preschool. These involved both outdoor and indoor spaces and facilities.
\end{abstract}

Keywords: learning with nature, indoor learning, outdoor learning, nature awareness 
PLANNING MALAYSIA

Journal of the Malaysia Institute of Planners (2018)

\section{INTRODUCTION}

Connecting children with nature contributes to their positive development. However, children and families nowadays often have limited opportunities to interact with the nature surrounding them. Children in modern families tend to spend more time watching television and playing computer games than playing outside of their houses. Modern societies seem to neglect the value of such environment for the development of children, and even for adolescents. With current development in the pedagogy of teaching and learning approaches in the world, not many studies have been done on outdoor learning in Malaysia (Spalie, Utaberta, Abdullah, Tahir, \& Ani, 2011). Most studies have focused on the development of curriculum and the delivery of knowledge, but not many approaches have been made to analyse outdoor learning as one of the alternative methods of learning in school design.

According to Komunitas Sekolah Alam recorded by Spalie et al. (2011), learning with nature is an approach to connect the children with nature. There are some research done in Indonesia that show the increase of understanding and interest up to $40 \%$ among the children that were involved with learning with nature teaching method. This research will provide an understanding of learning with nature from the perspective of pre-school educators in Malaysia. There are three objectives of the research: to gain the viewpoints of preschool educators on the importance of learning with nature; to study approaches to instil the awareness towards nature among preschool children; and to investigate the type of facilities and space needed for learning with nature.

\section{LEARNING WITH NATURE}

According to Wilson (2011), learning during early childhood progress is characterised by the significance of the child's innate drive to discover and learn. In this phase of early childhood, children develop their sense of affection toward the natural world and their insights into the needs of other creatures. The emphasis on environmental learning at this phase is to inspire children to explore and experience their local environment, and to encourage a sense of curiosity and sense of their place.

Humans have been created together with the natural environment and survive by learning how to use all the elements of the environment. The various components of nature in the earth hold the answer to every question (Hashim \& Denan, 2014). Moss added that nature is a tool for the children to explore not just the world, but also to explore themselves. Natural England (2012), stated that the natural environment includes all available outdoor green area where children can play. Such spaces allow for childhood discovery and learning, adventure and escape, or solely know-how about the changing seasons. 
Syaida Farizah Saleh, Nurul Syala Abdul Latip \& Asiah Abdul Rahim

Assessment of Learning with Nature in Preschool

\section{IMPORTANCE OF LEARNING WITH NATURE}

According to Von Benzon (2017), beyond the psychological, the literature classifies discourses relating to a wide range of benefits, or rationalities, for offering opportunities for access to outdoor green space including the social, environmental, developmental, emotional and behavioural, and medical contexts. According to Ali, Rostam and Awang (2014), plants have an influence on human psychology. Students' interactions with plants could help to lessen the negative emotions, upsurge positive thoughts, reduces physical pressure and develops the students' attention towards learning. Interaction with the outdoor environment without any boundaries could diminish psychological pressure in our daily life. Nature can ease mental stress and illness (Hashim \& Denan, 2014). Natural England (2012) stated that children will do better than usual after activities in green settings and that the "greener" a child's play area, the less severe his or her attention deficit symptoms.

According to Hashim \& Denan (2014), nature provides a peaceful and motivating environment and stimulate knowledge seeking, curiosity and attentiveness. Nature aids children's imagination in inspire design ideas. Mirrahimi, Tawil, Abdullah, Surat and Usman (2011) added that benefits of contacting the natural environment in learning area include boosting language improvement, improving academic achievement, improved the scores, enhanced opportunities for learning and increased educational performance. Natural environments stimulate social interaction and de-stressing through exercise or communication and provide a peaceful setting (Hashim \& Denan, 2014). Wilson (2011), said that experiences in nature can contribute to the healthy growth of a child's body, mind, and spirit. Natural England (2012), added that children could gain lifelong health benefits via exposure to the natural environment. In terms of social, children can learn to work together, take responsibilities, develop selfconfidence, cooperate, and develop a relationship between student and teacher during learning with nature (Mirrahimi et al., 2011).

It is important for children to be in an outdoor environment for the development of motor and cognitive skills. In an outdoor environment, children can learn through three modes of learning which are cognitive, affection, and the evaluation of either natural or man-made things (Aziz \& Said, 2012). Azlina and Zulkiflee (2010) said that natural environment can be a source for cooperative and imaginative play. This triggers children's curiosity and imaginative association. Learning with nature can develop awareness towards natural environment (Hashim \& Denan, 2014). Wilson (2017) added that a feeling of love and empathy towards nature grows out from children's regular contact with the natural world. 


\section{APPROACH TOWARDS LEARNING WITH NATURE}

According to Mirrahimi et al. (2011), learning does not occur only through formal education in the natural environment. Studies have also shown that informal education could happen in a natural context. Informal education is an important form of learning that occurs without teacher involvement. A school has to play the role of providing children with opportunities to experience a wide range of natural environments. By working together, the educational profession has the potential to inspire and enthuse children, provide them with memorable experiences, and empower them to make the most out of the natural spaces and places locally and further afield (Natural England, 2012).

According to Ali et al. (2014), a conducive landscape will assist directly or indirectly in the learning process. It will bring the children close to nature. Environmentally related activities such as $3 \mathrm{~K}$ programs as well as campaigns to recycle and reuse of waste materials not only increase security, safety, and cleanliness of the school compounds but also encourage students to love the environment (Ali et al., 2014). It is important to provide environmental education to create awareness about the environment among children (Acar, 2014). Acar added that outdoor class activities such as outdoor play create learning opportunities through trial knowledge and experience. Outdoor learning has been used as early-stage research at several preschool institutions in Indonesia especially in Jakarta (Spalie et al., 2011). According to Wilson (2017), unstructured activities in nature also can develop lifelong conservation values. This can facilitate environmentally informed and active children. Learning with nature also can be engaged in the form of training subjects such as math, science, language arts, environmental studies, and nutrition with the integration of core program standards (Mirrahimi et al., 2011). Wilson (2017) said that the recreational program outside of preschool is considered as part of free-choice learning in which children can absorb the information that they encountered by themselves. Children have to use all their senses to experience and appreciate the natural environment.

FACILITIES AND SPACE NEEDED FOR LEARNING WITH NATURE

According to Mirrahimi et al. (2011), a good design for outdoor learning connecting with nature is important to promote student's abilities in terms of both academic achievement and social behaviours. A designed space for environmental learning can help to create a more childlike atmosphere. Designers pay more attention to shape and space shape combination, rather than the capabilities of the space that are important for people (Oloumi, Mahdavinejad, \& Namvarrad, 2012). Children are easily influenced by the surrounding environment. It affects children activities as well as children behaviour. It is important for designers to have deep knowledge about children, the nature of children's relationship with the environment, the needs and demands of children, 
Syaida Farizah Saleh, Nurul Syala Abdul Latip \& Asiah Abdul Rahim

Assessment of Learning with Nature in Preschool

and the opportunities that can be offered through the design of the learning environment in order to produce a high quality of learning environment for the children (Acar, 2014).

Ali et al. (2014) have stated that landscapes function in assisting the learning process involves the entire components of the landscape at schools and it includes hard components such as gazebo, pergola, bench, garden tables, fish pond, signboards, flower pots, and soft elements such as shade trees, plants, fruits, grass, herbs, and others. The landscape should include a range of different natural features such as sand, soil, grass, a variety of different plantings and trees. Abbas, Othman, Puteri, Megat and Rahman (2012) added that quality of organization and materialization of the designed physical environment of the premises correlates with the positive developmental results of children. A contemporary design of playgrounds did not necessarily promote greater amounts of educationally desirable social, language, or motor behaviours. Children need to have an environment that addresses them, challenges them, and provides something for them to observe and think about, to make choices, to attract their attention, to engage in their favourite activities and to give them the opportunity to meet friends. They also need the freedom to explore and satisfy their curiosity about the world (Aziz \& Said, 2012). Learning with nature should not be limited to outdoors. According to Mccurdy, Winterbottom, Mehta and Roberts (2010), having windows facing towards the vegetation view is also considered as connecting the children with nature.

Oloumi et al. (2012) have stated that children must deal with forms and buildings and also with connection and live inside them feel comfortable, not fear and relax. Spaces with spirited and light colour and often colours with unclear forms (like cases generated in watercolour painting) inspire imaginary topics and inspire feelings like kindness, sense of emotion. Challenges facing the preschool include fear of accidents, costs, and curriculum development (Natural England, 2012). According to Von Benzon (2017), preschools nowadays are designed to limit children's freedom of movement and ensure maximum opportunities for surveillance of children by responsible adults. Children are enclosed by walls and doors which totally separate them from the outside world. When designing a space for learning with nature, high levels of management and surveillance are often deemed necessary due to the potential risks during the learning process.

\section{METHODOLOGY}

The methodology employed in this research is a qualitative method. The two techniques used are structured interview and visual study. The visual study included photographing and observation checklists. The data were collected using case studies at four preschools: IIUM Montessori Gombak; Tadika Abim AlHuda, Bukit Baru, Melaka; Tadika Ceriaku, Sg. Rambai, Melaka; and AlBaghdadi Playtime Centre, Taman Bandar Senawang, Seremban. For the 
PLANNING MALAYSIA

Journal of the Malaysia Institute of Planners (2018)

structured interview techniques, three preschool educators from each preschool were interviewed. Preschool educators were chosen for the interviews as they have vast and reliable knowledge about preschool education and children. Interview sheet was prepared to assist the interviewer to ask the question to the respondent regarding the topic of research. Observations were carried out by identifying the space and facilities provided for the children and explore nature at preschool. A checklist was prepared beforehand to ensure that all areas concerned are covered and to establish a common baseline to compare between the four preschools.

\section{PERCEPTION FROM PRESCHOOL EDUCATORS ON THE IMPORTANCE OF LEARNING WITH NATURE}

The importance of learning of nature consists of emotion and psychology, learning performance, health, social, behaviour, motor and cognitive skills, play and environmental awareness. The table below describes the importance of learning with nature from the structured interview.

Table 1: Explanation of the importance of learning with nature

\begin{tabular}{|c|c|}
\hline $\begin{array}{l}\text { Importance of Learning } \\
\text { with nature }\end{array}$ & Explanation \\
\hline Emotion and psychology & $\begin{array}{ll}\text { - } & \text { Lessen negative emotion } \\
\text { - } & \text { Upsurge positive thoughts } \\
\text { - } & \text { Ease mental stress and illness } \\
\text { - } & \text { Happier and reduced violence } \\
\text { - } & \text { Reduced depression } \\
\text { - } & \text { Less deficit attention disorder } \\
\end{array}$ \\
\hline Learning performance & $\begin{array}{ll}\text { - } & \text { Explore new ideas } \\
\text { - } & \text { Develop interest and understanding on learning } \\
\text { - } & \text { Stimulate thinking } \\
\text { - } & \text { Lift problem-solving skills } \\
\text { - } & \text { Increase focus } \\
\text { - } & \text { Critical thinking } \\
\text { - } & \text { Self-directed learning } \\
\end{array}$ \\
\hline Health & $\begin{array}{ll}\text { - } & \text { Increase daily physical activities } \\
\text { - } & \text { Reduced childhood stress } \\
\text { - } & \text { Improved myopia and asthma } \\
\text { - } & \text { Prevent obesity } \\
\text { - } & \text { Healthy brain development } \\
\text { - } & \text { Improve chronic pain issues } \\
\text { - } & \text { Increase life expectancy } \\
\end{array}$ \\
\hline Play & $\begin{array}{l}\text { - } \quad \text { Source for cooperative and imaginative play } \\
\text { - } \quad \text { Diversity in play }\end{array}$ \\
\hline
\end{tabular}


Syaida Farizah Saleh, Nurul Syala Abdul Latip \& Asiah Abdul Rahim Assessment of Learning with Nature in Preschool

\begin{tabular}{lll}
\hline \multirow{3}{*}{ Social and behaviour } & - Social and constructive play \\
& - Increase socialization \\
& - Increase cooperation \\
& - Develop children-teacher \\
& - relationship \\
& - increase self-confidence \\
\hline Motor and cognitive & - Stimulate children senses \\
skills & - Generate cognitive skills \\
& - Improve eye-hand coordination \\
& - Improve hearing, seeing, touching and smelling \\
& - Improve concentration \\
\hline Environmental awareness & - Learn and understand nature \\
& - Instil awareness and appreciation towards nature \\
& - Develop responsibility and sensitivity towards \\
\hline
\end{tabular}

\section{THE APPROACH TO INSTIL THE AWARENESS TOWARDS} ENVIRONMENT AND NATURE AMONG PRESCHOOL CHILDREN

Approaches to instil the awareness towards the environment and nature among preschool children were asked about during the interview sessions. These approaches included landscape, environmental activities, outdoor class activities, free structured play, formal learning and recreational program outside of preschool. Table 2 shows details on the approaches to instil awareness towards the environment and nature.

Table 2: Details on the approaches to instil awareness towards environment and nature

\begin{tabular}{|c|c|}
\hline Approach & Details \\
\hline Conducive landscape & $\begin{array}{l}\text { - } \text { Garden areas that include plantation on the ground, fish } \\
\text { - } \quad \text { Open space for unstructured play } \\
\text { - } \quad \text { Playground area } \\
\text { - } \quad \text { Rest area like the gazebo }\end{array}$ \\
\hline $\begin{array}{l}\text { Environmental } \\
\text { activities }\end{array}$ & $\begin{array}{ll} & \text { Recycle art and craft activities } \\
\text { - } & \text { Video demonstration of recycling materials }\end{array}$ \\
\hline $\begin{array}{l}\text { Outdoor class } \\
\text { activities }\end{array}$ & $\begin{array}{ll}\text { - } & \text { Gardening activities } \\
\text { - } & \text { Nature walk } \\
\text { - } & \text { Finding living things }\end{array}$ \\
\hline $\begin{array}{l}\text { Free and } \\
\text { unstructured outdoor } \\
\text { play }\end{array}$ & $\begin{array}{l}\text { - } \quad \text { Water and sand play } \\
\text { - } \quad \text { Free time play }\end{array}$ \\
\hline Formal education & $\begin{array}{l}\text { - Learning with nature through subjects such as Science, } \\
\text { Mathematics, and Islamic Teaching }\end{array}$ \\
\hline
\end{tabular}


PLANNING MALAYSIA

Journal of the Malaysia Institute of Planners (2018)

\begin{tabular}{lll}
\hline Recreational & $\bullet$ & Visit nearby parks \\
$\begin{array}{l}\text { program outside } \\
\text { preschool- }\end{array}$ & $\bullet$ & Visit Aquaria, KLCC, bread factory and Farm in the \\
& City \\
\hline
\end{tabular}

From the identified approaches, space and facilities needed for learning with nature were identified as follows:

- Garden area that includes plantation and animal

- Open space for unstructured play

- A classroom that integrates an outdoor environment

- Rest area

- Water and sand play area

- Playground area

- Recycle area

THE TYPE OF FACILITIES AND SPACE NEEDED FOR LEARNING WITH NATURE

The types of facilities and spaces needed for learning with nature were described in terms of three aspects, which are children's preferences on the setting of space, the physical aspects, and design concerns. Few guidelines on setting the space have been identified. The tables below show the findings on the types of facilities and space needed for learning with nature.

Table 3: Children preference on the setting of space for learning with nature

\begin{tabular}{ll}
\hline $\begin{array}{l}\text { Playground vs open } \\
\text { space }\end{array}$ & $\begin{array}{l}\text { Children prefer to play at playground since they were exposed } \\
\text { more to that type of setting. However, educators prefer to have } \\
\text { an open space as a play area. Children can explore and learn } \\
\text { more at open space play area. }\end{array}$ \\
\hline $\begin{array}{l}\text { Natural furniture vs } \\
\text { modern furniture }\end{array}$ & $\begin{array}{l}\text { Children are attracted to both types of furniture. Both types of } \\
\text { furniture can be designed without sharp edges that can harm } \\
\text { children. }\end{array}$ \\
\hline $\begin{array}{l}\text { Living things vs } \\
\text { visual 2-dimension }\end{array}$ & $\begin{array}{l}\text { Children prefer to learn with living things for which they can } \\
\text { use their senses of smell, hearing, sight and touch. }\end{array}$ \\
\hline Outdoor vs indoor & $\begin{array}{l}\text { Children prefer outdoor class rather than an indoor class } \\
\text { because they have more freedom outside. }\end{array}$ \\
\hline
\end{tabular}

Source: Author

Table 4: Physical aspect needed for learning with nature

\begin{tabular}{lll}
\hline & & \multicolumn{1}{c}{ Outdoor landscape features } \\
\hline - & Natural & - Various types of plants are needed for outdoor landscaping. \\
- & Plants & This can provide diversity in play and also give shade for \\
- & Animal & children to rest. \\
- & Sand/soil & - Animal facilities should be provided to educate kids to love \\
& & animals. \\
\hline
\end{tabular}


Syaida Farizah Saleh, Nurul Syala Abdul Latip \& Asiah Abdul Rahim Assessment of Learning with Nature in Preschool

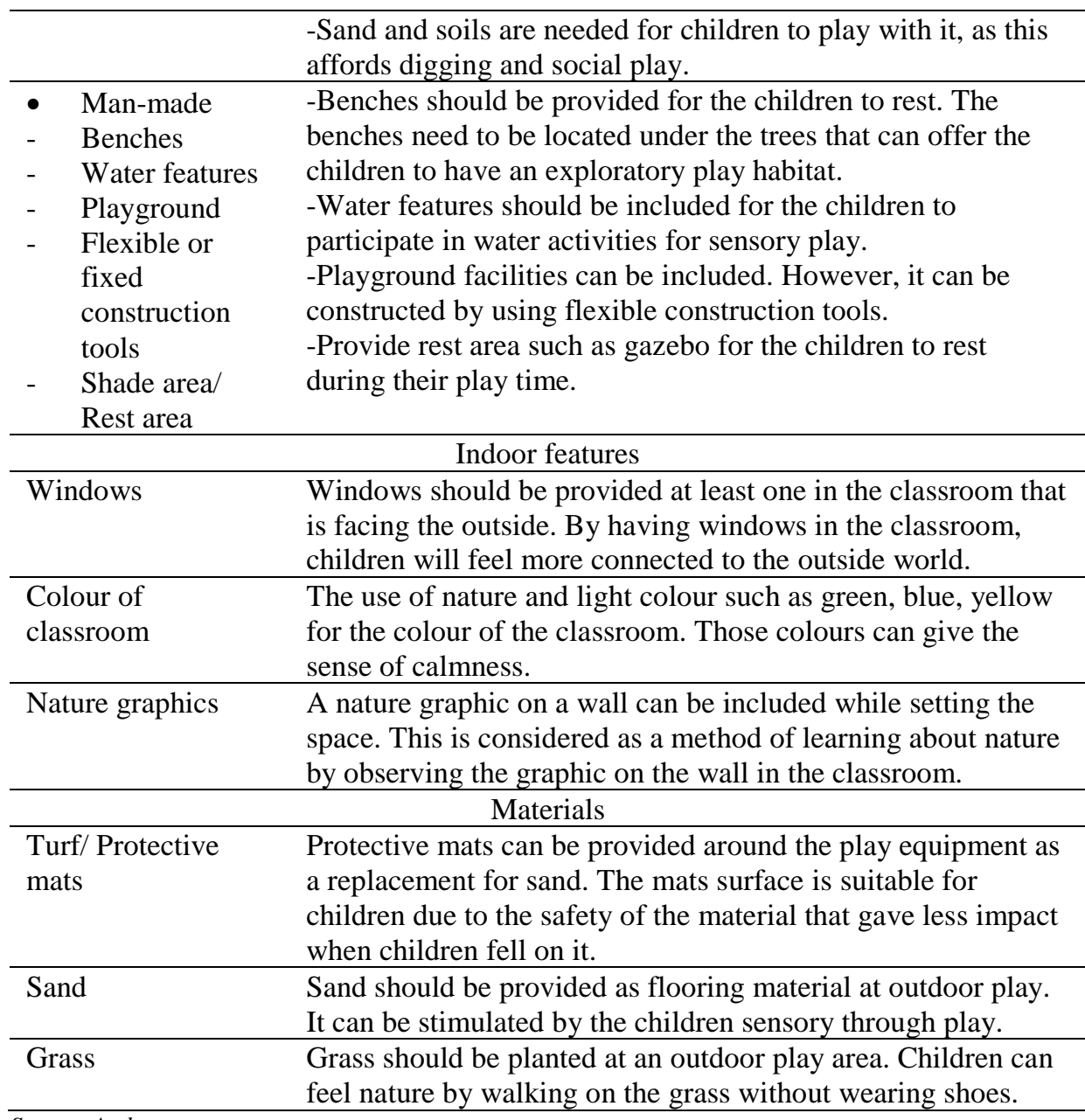

Source: Author

Table 5: Concern in designing the space for learning with nature

\begin{tabular}{ll}
\hline Air pollution & $\begin{array}{l}\text { Need to ensure the condition of the site to prevent exposure to } \\
\text { poor air quality that is not good for health. }\end{array}$ \\
\hline Accidents and & $\begin{array}{l}\text { Spaces should be designed in such a way that they will not } \\
\text { trigger any kind of accidents and injury. Sharp edges need to } \\
\text { be avoided. The chosen of flooring must be suitable for } \\
\text { children who love to run. }\end{array}$ \\
\hline Teacher supervision & $\begin{array}{l}\text { Space should be designed to enable teachers to observe. Fewer } \\
\text { walls can improve the supervision of the space. }\end{array}$ \\
\hline Insect bites and \\
stings
\end{tabular} \begin{tabular}{l}
$\begin{array}{l}\text { Study is required of the context of the natural surroundings, } \\
\text { such as whether there are insect or animal species that are } \\
\text { dangerous to people. }\end{array}$ \\
\hline
\end{tabular}


Source: Author

\section{CONCLUSION AND RECOMMENDATION}

Learning with nature is important for children in many aspects such as emotion, psychology, health, behaviour, social, motor and cognitive skills, play, and environmental awareness. Learning with nature can be applied in both indoor class and outdoor classes. Indoor class involve formal learning, while outdoors involves informal learning. From this paper, the type of space and facilities that support learning with nature were identified. All research questions were answered with the support from the primary and secondary data. The primary data gained from data collection is compared to the secondary data which is the literature review to gain the final output of the research. From the discussion, the author can conclude that learning with nature can be applied in teaching and physical treatment approaches by instilling awareness of nature and environment among the preschool children.

This research has only focused on the preschool educator's views on learning with nature. Educators' views are based on their experiences as educators. However, parents' views are also needed when setting the space and facilities for learning with nature since they are who are going to decide what is the best for their children. Thus, parents' views of learning with nature can be studied for future research. Additionally, the research only focuses on the facilities and space needed for learning with nature for preschool children. The integration of facilities and space needed for nature is not covered in this research. Therefore, future research should examine how to design the facilities and space of a preschool to be integrated with nature.

\section{ACKNOWLEDGEMENT}

The authors would like to acknowledge the Research Acculturation Grant Scheme (RAGS) from the Ministry of Higher Education for the support of this research.

\section{REFERENCES}

Abbas, M. Y., Othman, M., Puteri, \&, Megat, Z., \& Rahman, A. (2012). Pre-school Classroom Environment: Significant upon Childrens' Play Behaviour? Procedia -Social and Behavioral Sciences, 49, 47-65.

Acar, H. (2014). Learning environments for children in outdoor spaces. Procedia - Social and Behavioral Sciences, $141,846-853$.

Ali, S. M., Rostam, K., \& Awang, A. H. (2014). School landscape environments in assisting the learning process and in appreciating the natural environment. Procedia - Social and Behavioral Sciences, 202, 189-198.

Aziz, F., \& Said, I. (2012). The trends and influential factors of children's use of outdoor 
Syaida Farizah Saleh, Nurul Syala Abdul Latip \& Asiah Abdul Rahim

Assessment of Learning with Nature in Preschool

environments: A review. Procedia - Social and Behavioural Sciences, 38, 204212.

Azlina, W., \& Zulkiflee, A. S. (2010). A pilot study: The impact of outdoor play spaces on kindergarten children. Procedia - Social and Behavioural Sciences, 38, 275 283.

Hashim, H. H., \& Denan, Z. (2014). Importance of preserving the natural environment in the design schools in Malaysia. Procedia - Social and Behavioural Sciences, 170, 177-186.

Mccurdy, L. E., Winterbottom, K. E., Mehta, S. S., \& Roberts, J. R. (2010). Using nature and outdoor activity to improve children's health. YMPS, 40, 102-117.

Mirrahimi, S., Tawil, N. M., Abdullah, N. A. G., Surat, M., \& Usman, I. M. S. (2011) Developing Conducive Sustainable Outdoor Learning: The Impact of Natural environment on Learning, Social and Emotional Intelligence. Procedia Engineering, 20, 389-396.

Natural England (2012). Learning in the natural environment: Review of social and economic benefits and barriers (NECR092). Retrieved from http://publications.naturalengland.org.uk/publication/1321181

Oloumi, S., Mahdavinejad, M., \& Namvarrad, A. (2012). Evaluation of outdoor environment from the viewpoint of children. Procedia - Social and Behavioural Sciences, 35, 431-439.

Spalie, N., Utaberta, Abdullah, Tahir, M., \& Ani, C. (2011). Reconstructing sustainable outdoor learning environment in Malaysia from the understanding of natural school design and approaches in Indonesia. Procedia - Social and Behavioural Sciences, 15, 3310-3315.

Von Benzon, N. (2017). Unruly children in unbounded spaces: School-based nature experiences for urban learning disabled young people in Greater Manchester, UK. Journal of Rural Studies, 51, 240-250.

Wilson, C. (2011). Effective approaches to connect children with nature. Wellington: Department of Conservation. Retrieved from http://www.doc.govt.nz/Documents/getting-involved/students-and-teachers/ effective -approaches-to-connect-children-with-nature.pdf 